\title{
Cats and dogs cross the line: domestic breeds follow Rensch's rule, their wild relatives do not
}

\author{
C.J. Bidau ${ }^{1} \otimes$, P.A. Martínez ${ }^{2} \otimes$
}

1 Olaguer 444, Lomas del Mirador, Provincia de Buenos Aires, 1752, Argentina
2 PIBi Lab - Laboratorio de Pesquisas Integrativas em Biodiversidade, Departamento de Biologia, Universidade Federal de Sergipe, Av. Marechal Rondon,
S/N - Jardim Rosa Elze, São Cristovão, 49100-000, Brazil

The domestication syndrome already recognized by Darwin shows that domesticated species acquire a number of novel morphological, physiological and behavioral characteristics not present in their wild ancestors. Because body size and sexual size dimorphism (SSD) are essential characteristics of species that affect most aspects of their life histories, we studied the effects of domestication on body size and SSD in domestic dogs and cats in comparison with their wild relatives: the Canidae and Felidae, respectively, and also analyzed the occurrence of Rensch's rule within both domestic species. We studied maximum body mass and maximum height at withers of 64 and 89 domestic dog breeds respectively, and maximum body mass of 37 domestic cat breeds as well as body mass data for 36 wild Canidae and 36 wild Felidae from our previous studies. Our results have shown that domestic dogs maintain a level and range of body mass which largely exceeds that of the Canidae as a whole while maintaining a similar degree and range of SSD. On the contrary, domestic cats show a much reduced body mass range within the limits of their ancestor species while showing comparable levels of SSD as shown by the Felidae. Regarding Rensch's rule, both Reduced Major Axis and Ordinary Least Squares regressions showed that both domestic species present a scaling of male and female body sizes consistent with Rensch's rule while their wild relatives do not. We discuss these findings in the light of present knowledge about the domestication of Canis familiaris and Felis catus.

Key words: Canis familiaris; Felis catus; Canidae; Felidae; domestication; sexual size dimorphism; reduced major axis regression; body size.

\section{Кошки и собаки, в отличие от их диких сородичей, соблюдают правило Ренша}

\author{
К.Х. БиАау ${ }^{1} \otimes$, П.А. Мартинес ${ }^{2} \otimes$ \\ 1 Олагер 444, Ломас-дель-Мирадор, провинция Буэнос-Айрес, \\ 1752, Аргентина \\ 2 Лаборатория комплексных исследований биоразнообразия \\ отдела биологии Федерального университета Сержипи, \\ просп. Марешал Рондон, Жардин Роза Элзи, Сан-Кристован, \\ 49100-000, Бразилия
}

Синдром доместикации, обнаруженный Чарльзом Дарвином, показывает, что доместицированные виды приобрели ряд новых морфологических, физиологических и поведенческих характеристик, которых не было у их диких предков. Поскольку размер тела и половой диморфизм по размеру тела (ПДРТ) являются важнейшими видовыми характеристиками, влияющими почти на все аспекты жизни животных, мы изучили влияние доместикации на эти два показателя у домашних собак и кошек в сравнении с их сородичами: собачьими и кошачьими, а также проанализировали применимость правила Ренша для обоих домашних видов. В анализ были включены данные по максимальной высоте в холке у 89 пород собак и максимальной массе тела у 64 пород собак и 37 пород кошек. Кроме того, использованы данные по массе тела 36 диких видов собачьих и 36 видов кошачьих, полученные в ходе более ранних исследований. Результаты показали, что значения массы тела и их диапазон у домашних собак значительно превышают эти показатели у представителей семейства Canidae в целом, в то время как соответствующие показатели ПДРТ у них схожи. У домашних кошек диапазон значений массы тела укладывается в диапазон значений, характерных для их видов-предшественников, но при этом существенно сужен, тогда как значения соответствующих показателей ПдРТ сравнимы. Регрессии, полученные как стандартным методом главных осей (RMA), так и методом наименьших квадратов (OLS), показали, что у домашних видов размеры тела самок и самцов подчиняются правилу Ренша, а у их диких сородичей - нет. Данные результаты обсуждаются в свете существующих знаний о доместикации видов Canis familiaris и Felis catus.

Ключевые слова: Canis familiaris; Felis catus; Canidae; Felidae; доместикация; половой диморфизм по размеру тела; стандартный метод главных осей, регрессия; размер тела. 
$\mathrm{D}$ omesticated animals and plants are so commonplace either as pets or as human nourishment that most people tend to think they have always been with us (Glutton-Brock, 2012). However, domestication of a variety of species has been an evolutionary event, including many evolutionary processes, of the utmost importance for Homo sapiens and the Biosphere as a whole and started no more than $30-40,000$ years ago with the initial commensal relationship between early humans and wolves, the ancestors of the first domesticated species: the dog (Glutton-Brock, 2012; Larson, Fuller, 2014; Zeder, 2015). Several definitions of domestication have been produced along the years (see Bidau, 2009; Zeder, 2015) and for our purposes we will use one of the most recent, that of Zeder (2015): "Domestication is a sustained multigenerational, mutualistic relationship in which one organism assumes a significant degree of influence over the reproduction and care of another organism in order to secure a more predictable supply of a resource of interest, and through which the partner organism gains advantage over individuals that remain outside this relationship, thereby benefitting and often increasing the fitness of both the domesticator and the target domesticate".

For Charles Darwin the process of domestication and the study of domestic breeds was essential for the formulation of his evolutionary theory especially through the analogy between natural and artificial selection, and the idea of unconscious selection (Darwin, 1859, 1868, 1871; see Bidau, 2009 for a discussion of these topics). Darwin was also the first to note and discuss the existence of a "domestication syndrome": a series of common morphological characteristics (e. g. floppy ears, shortened and curly tails, smaller brain size, disproportionate dwarfism, piebald coats, etc.) not present in the wild ancestors, appeared repeatedly in almost all domesticated mammals (Bidau, 2009; Larson, Fuller, 2014; Wilkins et al., 2014; Sánchez-Villagra et al., 2016). The ubiquity of these changes in many disparate species led early authors to think there was a single process involved in domestication which was a consequence of direct human action. The first evidences that this was probably not so simple came from a long-term evolutionary experiment initiated in 1959 by the Russian geneticist Dmitry Konstantinovich Belyaev in silver foxes (Vulpes vulpes) (Belyaev, 1979; Belyaev, Trut, 1982; Trut, 1999; Trut et al., 2007; Bidau, 2009). Belyaev reproduced the domestication syndrome in his farm foxes in a few generations by just selecting for tameness (no direct selection for any morphological traits) (Trut, 1999; Bidau, 2009). Today, it is recognized that the domestication process can follow several different pathways (Zeder, 2012, 2015; Larson, Fuller, 2014).

As mentioned above, one of the traits involved in the domestication syndrome is wide variability in body size of domesticated breeds with respect to their wild ancestors. Body size is of the utmost importance in animal evolution because it is related to almost all life history characteristics and in turn is affected by most environmental factors (Peters, 1983; Calder, 1984; Schmidt-Nielsen, 1984). Intimately linked to animal body size variation is the phenomenon termed sexual size dimorphism or the different sizes of males and females of the same species (Darwin, 1871; Fairbairn, 1997, 2007, 2013; Fairbairn et al., 2007). The study of the proximate and ultimate causes of SSD, a pervasive phenomenon in the animal kingdom, is of fundamental evolutionary importance because disentangling its causal mechanisms could lead to a better understanding of the workings of evolutionary forces. Sexual selection has usually been invoked as the main cause behind SSD (Darwin, 1871; Andersson, 1994; Isaac, 2005) an idea rejected by the co-discoverer of natural selection, Alfred Russel Wallace (Wallace, 1889). However, it is true that cases of SSD could be explained by natural selection for example through sexual segregation or fecundity selection in females (Isaac, 2005; Ruckstuhl, Neuhaus, 2005).

Associated to the problem of SSD is that of Rensch's rule. Evolutionary biologist Bernhard Rensch proposed in 1950 a hypothesis that in taxa where males are consistently larger than females (as in most mammals) SSD increases with increasing body size when comparing related species. Later Rensch (1960) proposed that when females are the larger sex (as in most invertebrates and some vertebrates including some mammals) SSD should decrease with increasing body size. This pattern was later called Rensch's rule (Abouheif, Fairbairn, 1997; Bidau, Martí, 2008b). Evidence for Rensch's rule at the interspecific level in different animal taxa is contradictory, and the mechanisms involved when it does occur are less understood than those explaining SSD (see Discussion). However, a number of cases including mammalian species are known where the rule operates intraspecifically (e.g. Bidau, Martí, 2008a; Martínez, Bidau, 2016).

Our aim was to analyze the levels and variation of body size and SSD at the intraspecific level in different breeds of two emblematic domesticated species: the dog, Canis familiaris and the cat, Felis catus and to compare them with their wild relatives using body mass and linear measurements. The study of body size and SSD evolution through domestication in dogs and cats is highly relevant for four important reasons: (i) our previous comparative studies have demonstrated that canids and felids do not follow Rensch's rule at the crossspecies level and that the two families greatly differ from each other in their levels of SSD in relation with their different reproductive strategies and social systems. Felids are polygynic and show high levels of male-male competition to access females, thus sexual selection favours large male size and increased SSD while canids are essentially monogamous, sexual male-male contests are rare and sexual selection does not favor exaggerated body size of males, hence lower SSD (Martínez et al., 2014; Bidau, Martínez, 2016); (ii) because in domestic breeds size and SSD are not only a consequence of natural or sexual selection in their wild ancestors but also of self-domestication, artificial and unconscious selection along their domestication pathways, changes in both traits could be expected since body size (thus, SSD) is extremely sensible to an enormous set of ecological and evolutionary factors. Changes in SSD could also be reflected in the presence or absence of Rensch's rule; (iii) it has been shown for dog and cat breeds that body size is negatively associated with lifehistory traits such as longevity (Galis et al., 2007; Greer et al., 2007; O'Neill et al., 2015) and, in cats SSD is correlated with retroviral infections and age at maturity (Pontier et al., 1998); and (iv) both domestic species include many breeds with large variation in body size and the data are easily accessible. 


\section{Materials and methods}

We collected measurements of male and female maximum body mass (BM) for 64 dog breeds and 37 cat breeds from data compiled in Bell et al. (2012) (Appendices 1, 2)1 . Data of BM of 36 wild Canidae and 36 wild Felidae were obtained from the published literature including our own previous work (Martinez et al., 2014; Bidau, Martinez, 2016). Body mass is the most widely collected body size estimator in Carnivora and the most used in studies of ecogeographic and evolutionary rules (e.g. Martinez et al., 2014; Meiri et al., 2014; Bidau, Martinez, 2016; Torres-Romero, Olalla-Tárraga, 2016). Because data on BM are widely available, comparisons between domesticated and wild species are facilitated. As an additional body size estimator in the dog we used maximum height at withers (HW) of 89 domestic breeds (Bell et al., 2012) (Appendix 1). Contrary to BM, HW is not a common or standard measurement for domestic cat breeds or wild canid and felid species. Generally, larger individuals tend to be described earlier than smaller ones (Collen et al., 2004). This is the reason behind the adoption by us of maximum BM and HW to perform all our analyses because measurements of a central trend such as the mean or the median will tend to decrease as new populations and individuals are sampled. For the statistical analyses both measurements, BM and HW were transformed to decimal logarithms. As an estimator of SSD for both body size measurements we used the ratio male size/female size (Fairbairn, 1997).

To test for the applicability of Rensch's rule to the domestic breeds we used two methodological approaches. First, we performed regressions between $\log _{10}$ (Male Size) and $\log _{10}$ (Female Size) (Abouheif, Fairbairn, 1997; Fairbairn, 1997). Because there is error in the size estimator used as predictor (independent) variable (female size in our analyses) the use of Model I regressions (e.g. OLS, Ordinary Least Squares) is not recommended. Thus, following Fairbairn (1997) we performed Model II regressions of the Reduced Major Axis type (RMA) to estimate the intercept (a) and the slope (b) of the relationship between male and female body sizes, as well as the coefficient of determination $\left(r^{2}\right)$. When the relationship conforms to Rensch's rule, we expect the RMA regression slope to be significantly larger than 1.0. Slopes that are significantly lower than 1.0 signal Rensch's rule inversion. Slopes not different from 1.0 indicate sexual isometry (Fairbairn, 1997). Also, an isometric relationship is indicated when the intercept of the regression function is not different from 0 (Ranta et al., 1994). To test the null hypotheses that $\mathrm{bRMA}=1.0$ and $\mathrm{aRMA}=0$ we calculated $95 \%$ confidence intervals for each parameter. As an additional confirmatory analysis of the RMA regression results, we estimated the relationship between SSD and $\log _{10}$ (Male Body size) using OLS regressions. We used male body size as the response variable because males showed higher variability than females in our samples (see results). For both approaches $\left(\log _{10}(\right.$ Male Size $) \sim$ $\log _{10}($ Female Size $)$ and $\log _{10}$ (Male Size $) \sim$ SSD $)$ we estimated the model's fit through $r^{2}$ and the statistical significance through permutation analysis (1000 interactions).

Finally, to assess the effects of domestication on the evolution of BM and SSD we performed $t$-tests between the

\footnotetext{
${ }_{1}^{1}$ Appendices 1, 2 are available in the online version of the paper: http://www.bionet.nsc.ru/vogis/download/pict-2017-21/appx7.pdf
}

domestic breeds and their wild relatives. All analyses were performed in the R 3.2.2, platform with the help of the lmodel2 package (Legendre, 2015).

\section{Results}

\section{Variation of body size and SSD in domestic dogs and cats}

Maximum Body Mass of dogs (BM) in the analyzed breeds varied between 3.63 and $77.18 \mathrm{~kg}$ in males $(\bar{x}=32.74 \mathrm{~kg}$; $\mathrm{CV}=56.8)$ and $3.63-59.02 \mathrm{~kg}$ in females $(\bar{x}=27.55 \mathrm{~kg}$; $\mathrm{CV}=53.3$ ) (Appendix 1). Our results indicate that domestic dogs show a higher mean BM and also a wider BM range than the 36 studied members of the canid family (Fig. 1). When only the extant wild species of canids were considered, mean body mass ranged between 7.6 and $45 \mathrm{~kg}$ in males $(\bar{x}=17.2 \mathrm{~kg}$; $\mathrm{CV}=71.5)$ and 6.6 and $30.1 \mathrm{~kg}$ in females $(\bar{x}=14.2 \mathrm{~kg}$; $\mathrm{CV}=62.0$ ). SSD of domestic dog breeds varied between 1.0 (Shih Tzu, Poodle Toy, Poodle Miniature, Dandy Dinmont Terrier and Bearded Collie breeds) and 1.46 (Airedale Terrier), with a mean SSD of 1.19 (Fig. 1; Appendix 1). Besides the five non-dimorphic (SSD = 1.0) breeds, the rest $(92 \%)$ showed clear male-biased SSD (>1.0) (Appendix 1). On the other hand, the domestication process seems not to have produced a significant level of variation of SSD in dogs with respect to their wild relatives since their comparison gives a non-significant result ( $p=0.397$ ) (Fig. 2). Mean SSD for Canis species ranged between 0.95 and $1.45(\bar{x}=1.18)$, almost the same as in domestic dogs.

Maximum Height at Withers of dogs (HW) varied between 24.75 and $81.0 \mathrm{~cm}$ in males $(\bar{x}=59.0 \mathrm{~cm} ; \mathrm{CV}=21.95)$ and $26.5-76.0 \mathrm{~cm}(\bar{x}=56.0 \mathrm{~cm}$; CV $=21.70)$ in females (Appendix 1). SSD varied between 0.91 and $1.13(\bar{x}=1.06)$ (Appendix 1). Four breeds exhibited moderate female-biased SSD $(<1.0)$ for HW (Beauceron, Cane Corso, Shih Tzu, and Tibetan Mastiff); seven breeds were monomorphic (SSD = 1.0) (Akita, Cardigan Welsh Corgi, Cavalier King Charles Spaniel, Lakeland Terrier, Pembroke Welsh Corgi, Plott Hound, and Miniature Poodle) and the rest $(88 \%)$ showed male-biased SSD (b > 1.0) (Appendix 1).

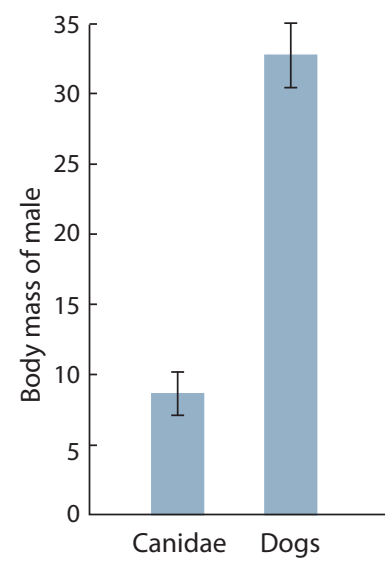

Fig. 1. A comparison of mean maximum male body mass, its range and standard deviation in wild Canidae and domestic dogs.

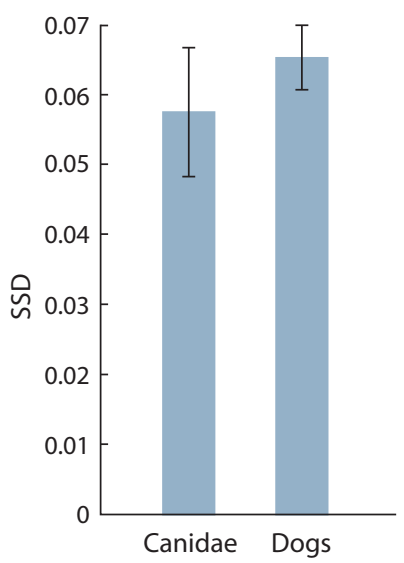

Fig. 2. A comparison of Sexual Size Dimorphism (SSD), its range and standard deviation in wild Canidae and domestic dogs. 


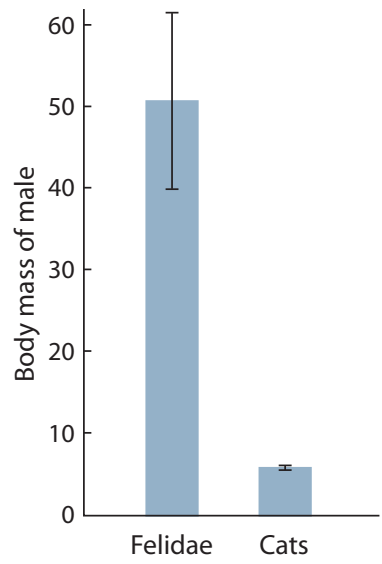

Fig. 3. A comparison of mean maximum male body mass, its range and standard deviation in wild Felidae and domestic cats.

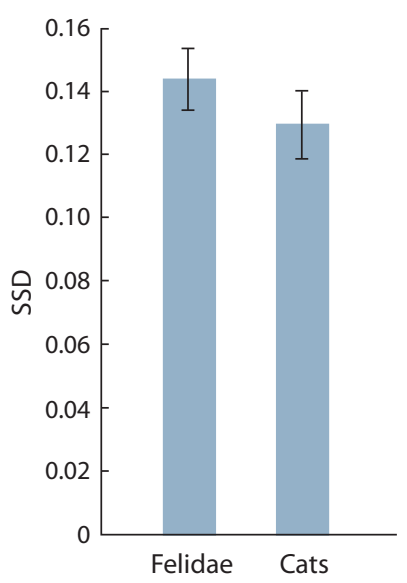

Fig. 4. A comparison of Sexual Size Dimorphism (SSD), its range and standard deviation in wild Felidae and domestic cats.

Maximum body mass of male cats varied between 3.63 and $9.98 \mathrm{~kg}(\bar{x}=5.8 \mathrm{~kg} ; \mathrm{CV}=27.58)$, and $2.72-6.81 \mathrm{~kg}$ $(\bar{x}=4.28 \mathrm{~kg} ; \mathrm{CV}=25.1)$ in females (Appendix 2). Domestication seems to have produced a sharp decline in BM of domestic cats which also show a narrow range for this trait as compared with its wild relatives $(p<0.001)$ (Fig. 3). Extant Felis species show a body mass range of 1.86 to $9.0 \mathrm{~kg}(\bar{x}=4.76 \mathrm{~kg}$; $\mathrm{CV}=49.8)$, and $1.2-6.5 \mathrm{~kg}(\bar{x}=3.48 \mathrm{~kg} ; \mathrm{CV}=48.6)$ in

females. In contrast, SSD for BM of cats varied widely between 0.80 and $1.70(\bar{x}=1.35)$ with a clear bias towards males (SSD > 1.0) (Appendix 2). Only two breeds, American Shorthair and Kurilian Bobtail displayed female-biased SSD $(<1.0)$. Domestic cat SSD did not show a significant difference in relation to the SSD displayed by wild felids ( $p=0.319$ ) (Fig. 4). In extant species and subspecies of Felis, SSD ranged between 1.22 and $1.55(\bar{x}=1.37)$ and Felis silvestris lybica, the modern wild descendants of the domestic cat ancestor, $\mathrm{SSD}=1.24$.

\section{Assessment of Rensch's rule}

We explored the occurrence of Rensch's rule in domestic dogs and cats using two complementary approaches: (i) the relationship between $\log _{10}$ (male size) versus $\log _{10}$ (female size) using Model II RMA regression and (ii) the relationship of $\log _{\log 10}$ (male size) versus SSD using OLS regressions. In dogs, the scaling of SSD for BM and HW with body size showed that SSD increases significantly with body size indicating the operation of Rensch's rule (Table; Fig. 5, $a, b$ ). This was confirmed by the significant positive slopes of OLS regressions (Table; Fig. 5, $d, e$ ). In the case of cat breeds, they also show an SSD trend (for BM) which is consistent with Rensch's rule. In this latter case although the RMA slope $(b=1.06)$ falls within the limits of the $95 \%$ confidence interval, it does so very asymmetrically (closer to the lower limit), and the OLS regression shows a highly significant increase of SSD with male BM (Table; Fig. 5, $c, f$ ). $a$

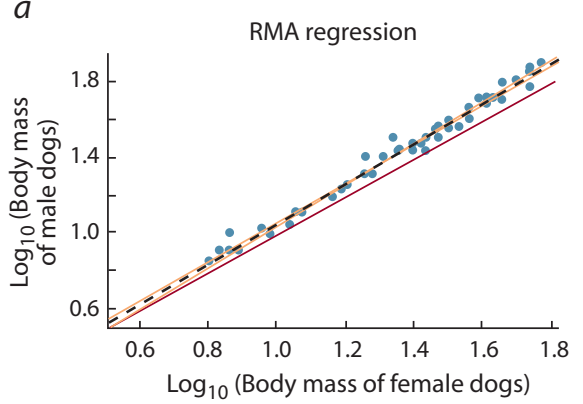

d

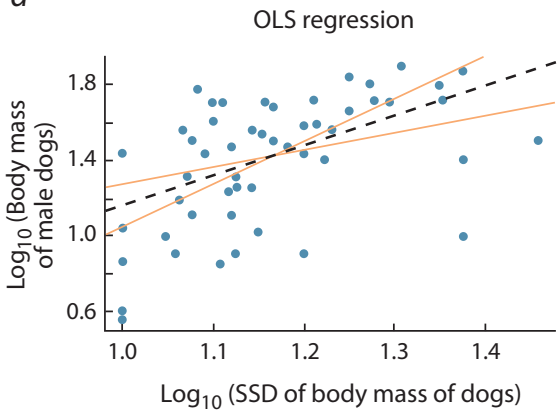

$b$

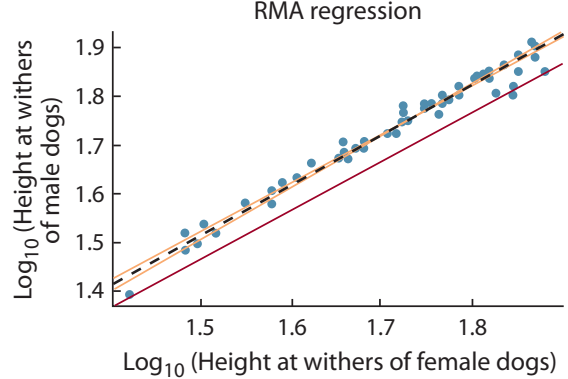

e

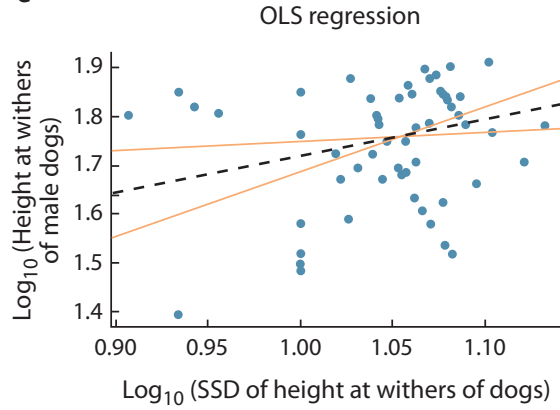

C

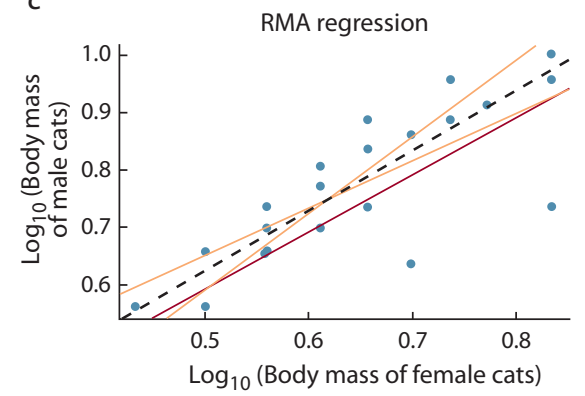

$f$

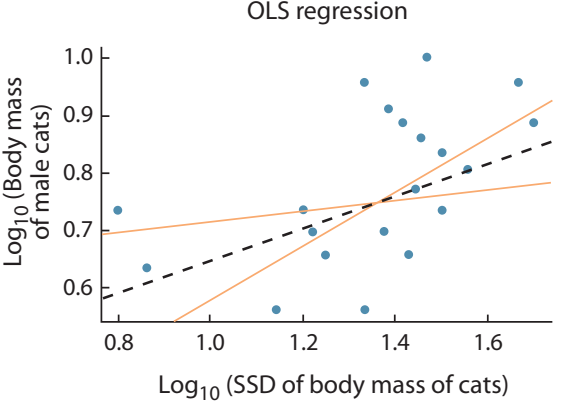

Fig. 5. $a-c$. Reduced Major Axis (RMA) regressions between: $a, \log _{10}$ (Maximum male body mass) vs. $\log _{10}$ (Maximum female body mass) of 64 dog breeds; $b, \log _{10}$ (Maximum male height at withers) vs. $\log _{10}$ (Maximum female height at withers) of 89 dog breeds; $c$, log 10 (Maximum male body mass) vs. $\log _{10}$ (Maximum female body mass) of 37 cat breeds. $d$ - $f$. Ordinary Least Squares (OLS) regressions between: $d$, log ${ }_{10}$ (Maximum male body mass) vs. $\log _{10}$ (SSD for Maximum body mass) (64 dog breeds); $e, \log _{10}$ (Maximum male height at withers) vs. log $\log _{10}$ (SSD for Maximum height at withers) (89 dog breeds); $f \log _{10}$ (Maximum male body mass) vs. $\log _{10}$ (SSD for Maximum body mass) (37 cat breeds).

In all cases, the $95 \%$ confidence limits accompany the regression line. In $a, b$, and $c$ the line corresponding to $b=1$ is shown. 
A summary of RMA and OLS regressions performed to assess the occurrence of Rensch's rule in domestic dog and cat breeds

\begin{tabular}{|c|c|c|c|c|c|c|c|c|c|}
\hline $\begin{array}{l}\text { Domesticated } \\
\text { group }\end{array}$ & Variable & Model & $\begin{array}{l}\text { Regression } \\
\text { type }\end{array}$ & a & $95 \% \mathrm{Cl}$ & $\mathrm{b}$ & $95 \% \mathrm{Cl}$ & $r^{2}$ & $p$ \\
\hline \multirow[t]{4}{*}{ Dog } & \multirow{2}{*}{$\begin{array}{l}\text { Maximum } \\
\text { Body Mass }\end{array}$} & Male_mass $\sim$ Female_mass & RMA & -0.017 & $-0.06 \_0.02$ & 1.06 & 1.03_1.09 & 0.98 & $<0.001$ \\
\hline & & Male_mass SSD_mass & OLS & -0.41 & $-1.19 \_0.37$ & 1.57 & $0.90 \_2.24$ & 0.26 & $<0.001$ \\
\hline & \multirow{2}{*}{$\begin{array}{l}\text { Height at } \\
\text { Withers }\end{array}$} & Male_height Female_height & RMA & -0.033 & $-0.09 \_0.03$ & 1.03 & 1.00_1.07 & 0.97 & $<0.001$ \\
\hline & & Male_height SSD_height & OLS & 0.96 & $0.38 \_1.55$ & 0.75 & 0.19_1.31 & 0.08 & 0.009 \\
\hline \multirow[t]{2}{*}{ Cat } & \multirow{2}{*}{$\begin{array}{l}\text { Maximum } \\
\text { Body Mass }\end{array}$} & Male_mass $\sim$ Female_mass & RMA & 0.09 & $-0.08 \_0.24$ & 1.06 & $0.82 \_1.34$ & 0.67 & $<0.001$ \\
\hline & & Male_mass SSD_mass & OLS & 0.36 & 0.10_0.62 & 0.28 & $0.09 \_0.46$ & 0.20 & 0.004 \\
\hline
\end{tabular}

RMA, Reduced Major Axis regression; OLS, Ordinary Least Squares regression; a, Regression intercept; b, Regression slope; Cl, 95 \% Confidence interval; $r^{2}$, Coefficient of determination; $p$, Statistical significance.

\section{Discussion}

Our results have shown that two emblematic domesticated species, the dog and the cat follow a sexual dimorphism trend in size that conforms to the empirical pattern known as Rensch's rule which is not present at the interspecific level in their respective families (Martínez et al., 2014; Bidau, Martínez, 2016). We have also demonstrated that in dogs, body size variation and SSD between breeds vary more than in the Canidae as a whole, while cats show a much lower size variation than that of the Felidae but SSD variation between breeds is comparable to that of the whole family. Why and how domestication produced these results? Ever since Darwin, sexual size dimorphism (SSD) became a fascinating biological problem that has engaged researchers in a large number of studies and a lot of controversy (Reiss, 1989; Andersson, 1994; Fairbairn et al., 2007; Fairbairn, 2013). SSD has been aptly called a biological enigma (Fairbairn, 2007) because despite its ubiquity in the animal kingdom, its causes and consequences are so difficult to disentangle that most hypotheses regarding the origin of SSD tend to be unsatisfactory (Reiss, 1989). Sexual selection, sexual segregation, fecundity selection, and other factors may be involved and their outcome is a certain statistical difference in size (body mass, length, height, etc.) between the sexes either male-biased as in most mammals and birds, or female-biased as in many invertebrates (Fairbairn, 2013). SSD is not a species trait comparable to body size which can be measured in kilograms or milligrams or in units of length: it is an unitless statistical parameter that varies according to the measurement used to estimate size (e.g. body mass and length in canids; Bidau, Martínez, 2016). Measurements of SSD using two different proxies for body size (e. g. mass and length) may or may not be not statistically correlated (e.g. correlation in felids, lack of correlation in canids; Martínez et al., 2014; Martínez, Bidau, 2016). It is not surprising that, differently from body size, SSD frequently does not show phylogenetic signal. Most explanations of SSD are probably incomplete since sexual and natural selection in their diverse modes can be jointly operating in complex ways. In this sense, an integrative theory that accounts for SSD taking all these caveats into consideration is that of Blanckenhorn (2005): the differential equilibrium model which proposes that SSD of a species is a result of opposing selective forces that equilibrate differently in both sexes.
Allied to this SSD enigma sensu Fairbairn (2007) is that of the so called Rensch's rule. The idea that SSD should increase with body size when males are larger than females, while decreasing in the opposite situation is so controversial that Rensch's rule (so named by Abouheif and Fairbairn, 1997) can hardly be considered a rule at all because of its numerous exceptions and inversions. Rensch's rule has been tested at the cross-species level within orders, families and genera of the most diverse animals in phylogenetically controlled and non-controlled comparative analyses. The results are so diverse that Rensch's rule can hardly be considered a general phenomenon. Moreover, since the possible causes of SSD are so different, it is difficult to envisage a single mechanism explaining Rensch's rule even when it is empirically verified. For example, some authors have proposed sexual selection as the basis of Rensch's rule. Sexual selection can effectively explain cases of SSD, even extreme ones. In pinnipeds, there is a whole range of SSDs (male mass/female mass) from practically 1.0 (or $<1.0$ when males are slightly smaller than females) in monogamous species (e.g. Phoca and Monachus species; Lindenfors et al., 2002) to species where males are several times heavier than females in extremely polygynous mating systems (e.g. Mirounga, Zalophus, Arctocephalus and Odobenus; Lindenfors et al., 2002), but Rensch's rule does not occur in pinnipeds: body size of males and females maintain an isometric scaling throughout the whole size range of the taxonomic group independently of mating system and the degree of SSD (Weckerly, 1998; Lindenfors et al., 2007). Some models apply only to a restricted group of animals: for example, metabolic scaling has been suggested as a cause for Rensch's rule in large mammalian herbivores (bovids, cervids and macropodids) and is based in that female group size increases with increasing body size and males must grow large enough through sexual selection to control these groups (Sibly et al., 2012). Most species of birds with female-biased SSD follow a trend that is the inverse to Rensch's rule: SSD increases with body size, or do not show a trend at all (Tubaro, Bertelli, 2003; Székely et al., 2007; Webb, Freckleton, 2007) despite claims that sexual selection is the ultimate cause of Rensch's rule in birds (Dale et al., 2007). The same can be said about other animal groups, vertebrate or invertebrate, where Rensch's rule has been tested at varying taxonomic levels (orthopteroid insects, Bidau et al., 2016; spider crabs, 
Simpson et al., 2016; anurans, Liao et al., 2013; reptiles, Cox et al., 2007; most mammals at the ordinal level, Lindenfors et al., 2007; Primates, Smith et al., 2002). Furthermore, the taxonomic level at which Rensch's rule has been analyzed is certainly variable, a problem shared by the study of other evolutionary or ecological rules. In Rensch's (1950) original paper, he implied that the pattern appeared when comparing closely related species (same genus or very phylogenetically close ones). He mostly used pairs of species of birds and mammals and eventually, several species (6) of Carabus beetles without performing thorough statistical analyses. In some groups with female-biased SSD such as the hemipteran family Gerridae (water-striders) Rensch's rule was verified in phylogenetically controlled studies at the familial and generic levels (Andersen, 1994; Abouheif, Fairbairn, 1997) and interestingly, the rule also applies within single species (e.g. Aquarius remigis) when different populations are analyzed (Fairbairn, 2005). Most other studies centered on whole tribes, subfamilies, families, orders and even classes of animals. There is no single explanation for the occurrence or absence of Rensch's rule at these different taxonomic levels, and as said by Reiss (1986) in a pioneering theoretical paper, no satisfactory explanation for Rensch's rule is available (see for example the highly speculative hypotheses in Dale et al., 2007).

SSD tends to have low or no phylogenetic signal (Martínez et al., 2014; Stevens, Platt, 2015; Bidau, Martínez, 2016; Martínez, Bidau, 2016), and as said above there is no convincing mechanism to explain Rensch's rule or its frequent inversion. The possible reason is that so many mechanisms are involved in the production of SSD that a single trend in scaling of SSD with body size does not exist. In fact, other more constant ecogeographic/evolutionary rules - which are in principle, empirical patterns - such as Bergmann's rule may also be explained in terms of very different ecological factors (Bidau, 2014). It is however noteworthy that very clear cases of Rensch's pattern have been uncovered within species of wide geographic distribution suggesting a relationship between ecogeographic body size variation and the degree of SSD (Blanckenhorn et al., 2006; Bidau, Martí, 2008a; Martínez, Bidau, 2014; Wu et al., 2014; Werner et al., 2016).

SSD of domesticated animals has received some attention (e. g. Lark et al., 2006; Sutter et al., 2008; Polák, Frynta, 2010; Reměs, Székely, 2010; Frynta et al., 2012) because it is well known that the process of domestication is usually accompanied by a "domestication syndrome". One of the "symptoms" of this syndrome is a generalized decrease in body size. It is thus reasonable to speculate that SSD would suffer from the joint action of new selective pressures arising from commensalism, autodomestication, and later and progressively, artificial and unconscious selection, and that domesticates would differ from their wild relatives in this respect.

\section{Body size and sexual size dimorphism of domestic dogs and cats}

The dog is the first species that was domesticated (probably autodomesticated in the beginning, much earlier than the start of conscious breeding by humans). It is generally accepted on the basis of archaeological and genetic findings that the timing of dog domestication dates from 15,000-16,000 BP (Late
Upper Palaeolitic) in East Asia (Larson et al., 2012; Perri, 2016). However, a recent molecular study (Skoglund et al., 2015) used genome sequencing of a 35,000 year old Siberian wolf to suggest that the ancestors of dogs were separated from present-day gray wolves before the Last Glacial Maximum. Also, Thalmann et al. (2013) analyzed mtDNA of prehistoric canids and modern dogs and wolves suggesting a European origin of domestication between 18,800 and 32,100 years ago started by prehistoric hunter-gatherers. However, since little is known about variation of palaeolitic gray wolf populations, these claims must be cautiously considered (Perri, 2016). As we have shown here, modern dogs show an impressive body size variation which largely exceeds that of the whole canid family. It is true that modern gray wolf populations may vary considerably in body size (see examples in Bidau, Martínez, 2016) although the range of variation is but a fraction of that of Canis familiaris. However, this difference has probably not been always so. Domestication of dogs has been a long process that probably included long periods of commensalism and autodomestication in different geographic areas and much more recently, the action of artificial selection accompanied by unconscious selection (Clutton-Brock, 2012). After all, most modern dog breeds were developed in the past 150 years deriving from a relatively homogeneous gene pool produced after several millennia of the admixture of different dog lineages as a result of human migration (Larson et al., 2012). Thus, most of the body size variation we observe today from Chihuahuas to Great Danes has been the consequence of conscious directed selection.

With respect to SSD of dogs, the story seems different. Modern breeds show a range of SSDs for body mass (1.00-1.46; $\bar{x}=1.17$ ) which is comparable to what is found within the different species of canids $(\bar{x}=1.15)$ with most species varying between 1.00 (the raccoon dog, Nyctereutes procyonoides) and 1.53 (the Bengal fox, Vulpes bengalensis) although a few species show slight female biased SSD, although dogs are more variable than all canids $(\mathrm{CV} \operatorname{dogs}=11.0 ; \mathrm{CV}$ canids $=8.6$ ). Different populations of modern gray wolves, the closest relatives of dogs, show some variation in body mass SSD (1.10-1.20) (Bidau, Martínez, 2016). The relatively low degree of SSD in canids as compared to other carnivores, has been attributed at the essentially monogamous mating system, reduced competition between males, and male involvement in the care of young of all wild species (Asa, Valdespino, 1998; Bidau, Martínez, 2016). Thus, sexual selection has probably played a lesser role in the development of canid SSD than in other carnivores (e.g. felids; see below). What about domestic dog SSD? The species has retained a potential to maintain the characteristic range of SSD of its family but what is the cause of such pronounced variation? Domestic dogs are not monogamous but promiscuous and lack paternal care of the young, although females tend to discriminate between familiar and unfamiliar males probably reflecting the monogamous mating system of their ancestors (Daniels, 1983; Lord et al., 2013). Although we do not know when this change of mating system started during the long process of domestication probably as an adaptation to the interaction with humans, it is not unreasonable that sexual selection may have played a major role in shaping SSD of the domestic dog, later further altered by human action during the creation of modern breeds but 
that could be operating today in feral and urban free-ranging dogs, although not in established breeds.

Today there is little doubt that all cats, both purebred and free-roaming, were domesticated from Felis silvestris lybica, one of five subspecies of this wild felid that inhabits North Africa and the Near East as shown by mtDNA and microsatellite DNA studies (Serpell, 2014). Archaeological and behavioral evidence also point to this subspecies (Serpell, 2014). Domestication probably started in the Fertile Crescent (western Asia) (Driscoll et al., 2007). The timing of domestication is uncertain but less so than that of dogs: 10,000 YBP Neolithic Levantine inhabitants were already taming wildcats (Vigne et al., 2004), an initial step towards domestication which significantly coincides with the presumed time of separation of the domestic cat lineage from F. silvestris lybica (Driscoll et al., 2007). The earliest known cat remains were found in Egypt dating from ca. 6,000 years ago (Serpell, 2014) while $\mathrm{Hu}$ et al. (2014) have reported the presence of cats dating between 5560-5280 YBP from an agricultural village in Shaanxi, China. Nevertheless, modern cat breeds representing full domestication are no more than 200 years old (Serpell, 2014). Contrary to the dog with its enormous range of body sizes, cats have maintained a relatively modest range of sizes that is very close to its ancestral species and subspecies (see data in Martínez et al., 2014) while the Felidae display an enormous range of body masses from $2-3 \mathrm{~kg}$ (e.g. the sand cat, Felis margarita) to $250 \mathrm{~kg}$ in males of Panthera tigris altaica, the Amur tiger (Martínez et al., 2014). This indicates a much lower genetic potential for variability of body size in the wild ancestor.

Regarding SSD of Felis catus, despite its relatively small size range it displays a range of $\operatorname{SSDs}(\bar{x}=1.36 ; \mathrm{CV}=13.2$; see Results) very similar to that of the whole family $(\bar{x}=1.44$; $\mathrm{CV}=15.4$; Martínez et al., 2014). Unlike canids, felid species are not monogamous but polygynous with no paternal investment and in such conditions sexual selection may play an important role in determining high levels of male-biased SSD. Free-ranging cats are polygynic and compete for females which perhaps choose their mates, with mating success strongly correlated with dominance (Liberg et al., 2000; Hart B., Hart L., 2014). Thus it is expected that domestic cats have been affected by sexual selection and the wide range of SSDs shown by modern breeds as described in this paper, is a derivative of their mating system, further affected by artificial selection. It would be desirable to have more body size data on free-roaming and feral populations of Felis catus in order to corroborate the previous assumptions.

\section{Rensch's rule in domestic dogs and cats}

Studies of Rensch's rule in domestic animals have been performed at different taxonomic levels and with variable outcomes and interpretations. Polák, Frynta $(2009,2010)$ studied SSD and Rensch's rule in domestic breeds of goats, sheep, and cattle, and their wild relatives. Domestic breeds followed Rensch's rule at the intraspecific level but their wild relatives did not just as in dogs and cats studied in this paper (canids and felids showed phylogenetically controlled bRMA $=1.06$ and $\mathrm{bRMA}=1.03$ respectively, both not statistically different from 1.0; Martínez et al., 2014; Bidau, Martínez, 2016). An identical situation occurs for the genera Canis and Felis which show $\mathrm{bRMA}=1.09$ and $\mathrm{bRMA}=0.97$ respectively in both cases not significantly different from 1.0 (Bidau, Martínez, unpublished data). However, these results must be cautiously interpreted due to the small number of species involved in the calculations. However, in cattle, when the size proxy was shoulder height, the Rensch's pattern disappeared. It must be remembered that in our sample of dog breeds, both body mass and height at withers showed Rensch's rule. Conversely, a study of domestic chicken breeds and their wild relatives revealed that the domestic breeds scaled isometrically for body size while the wild species showed Rensch's rule (Remeš, Székely, 2010).

Previous studies of dog breeds also showed disparate results. Sutter et al. (2008) studied 27 body measurements of 109 dog breeds and determined that male/female proportions were maintained in small and large breeds thus Rensch's rule cannot occur. However, Frynta et al. (2012) using shoulder height of 74 breeds obtained a significant positive allometric relationship between male and female size consistent with Rensch's rule. The occurrence of Rensch's rule in domestic dogs was confirmed by us using body mass as well as height at withers and there is little doubt that the trend exists. Cats were not previously studied in this respect and they also exhibit the Rensch's pattern while their wild relatives do not.

Thus, if we consider domestic mammals (goat, sheep, cattle, dogs and cats) a certain pattern emerges: despite the variations in size produced by domestication domestic mammals tend to maintain comparable levels of SSD as their wild relatives, but they follow Rensch's rule intraspecifically while the wild species do not in cross-species comparisons. Since patterns consistent with Rensch's rule have been found at the intraspecific level in several wild species-both vertebrate and invertebrate (see above), and fails to appear in many interspecific studies, we believe that the pattern in question is mainly a within-species phenomenon. No studies of intraspecific SSD variation have been performed in canids with the exception of dogs, but in Felidae we have found that seven different tiger subspecies obey Rensch's rule (bRMA = 1.56; $95 \% \mathrm{CI}=1.20-1.93 ; r^{2}=0.93$ ) (Martínez et al., 2014).

However, wild species and their domesticated derivatives obviously undergo very different selective pressures. In the wild, sexual selection has been probably very relevant in shaping SSD of felids but not of canids where natural selection (e. g. via sexual segregation) may have played a major role. In domesticates on the contrary, although these same forces could have been important in the first stages of domestication, once artificial (and unconscious) selection entered the scenario, selective pressures radically changed. But why Rensch's rule in domestic species? Originating in already size-dimorphic wild species, selection for large size, for example in males, would produce a correlative increase in female body size until natural selection puts a limit by selecting for an optimum body size of females which have a higher cost than males in reproductive terms (especially in polygynous cats without parental investment) (see Lande, 1980; Lark et al., 2006). Selection for small size would tend to equalize both sexes because among other factors, females would not have to pay the cost of carrying large sons.

Nevertheless, Rensch's rule remains as much an enigma as sexual size dimorphism and more studies are needed at the 
intraspecific level in wild and domesticated species in order to unveil the mechanism or mechanisms behind this elusive phenomenon.

\section{Acknowledgments}

We are extremely grateful to Dr. Pavel Mikhailovich Borodin for his kind invitation to publish our work in this memorial issue and giving us the possibility to honor that great geneticist and academician, Prof. Dmitry Konstantinovich Belyaev on the occasion of his $100^{\text {th }}$ anniversary. CJB heartily thanks María Gordo for her hospitality, friendship, care and patience during the writing of this paper in Buenos Aires city.

\section{Conflict of interest}

The authors declare that there are no conflicts of interest.

\section{References}

Abouheif E., Fairbairn D.J. A comparative analysis of sexual size dimorphism: assessing Rensch's rule. Am. Naturalist. 1997;149:540-562.

Andersen N.M. The evolution of sexual size dimorphism and mating systems in water striders (Hemiptera: Gerridae): a phylogenetic approach. Ecoscience. 1994;1:208-214.

Andersson M. Sexual Selection. Princeton, N. J., 1994.

Asa C.S., Valdespino C. Canid reproductive biology: an integration of proximate mechanisms and ultimate causes. Am. Zoologist. 1998; 38:251-259.

Belyaev D.K. Destabilizing selection as a factor in domestication. J. Heredity. 1979;70:301-308.

Belyaev D.K., Trut L.N. Accelerating evolution. Science in the USSR. 1982;5:24-29.

Bell J.S., Cavanagh K.E., Tilley L.P., Smith F.W.K. Veterinary Medical Guide to Dog and Cat Breeds. Jackson W. Y., 2012.

Bidau C.J. Domestication through the centuries: Darwin's ideas and Dmitry Belyaev's long-term experiment in silver foxes. Gayana. 2009;73(1):55-72. DOI 10.4067/S0717-65382009000300006.

Bidau C.J. Some historical aspects of ecogeographic rules: Bergmann's rule as an emblematic case. Entomol. Ornithol. Herpetol. 2014;2(3): $1-10$.

Bidau C.J., Marti D.A. Contrasting patterns of sexual size dimorphism in the grashoppers Dichroplus vittatus and D. pratensis (Acrididae, Melanoplinae). J. Orthoptera Res. 2008a;17:201-211.

Bidau C.J., Marti D.A. Rensch's rule in Dichroplus pratensis: a reply to Wolak. Ann. Entomol. Soc. Am. 2008b;101:802-803.

Bidau C.J., Martinez P.A. Sexual size dimorphism and Rensch's rule in Canidae. Biol. J. Linn. Soc. 2016;119:816-830. DOI 10.1111/Bij. 12848.

Bidau C.J., Taffarel A., Castillo E.R. Breaking the rule: multiple patterns of scaling of sexual size dimorphism with body size in orthopteroid insects. Revista de la Sociedad Entomológica Argentina. 2016;75:11-36.

Blanckenhorn W.U. Behavioral causes and consequences of sexual size dimorphism. Ethology. 2005;111:977-1016.

Blanckenhorn W.U., Stillwell R.C., Young K.A., Fox C.W., Ashton K.G. When Rensch meets Bergmann: does sexual size dimorphism change systematically with latitude? Evolution. 2006;60:2004-2011.

Calder W.A. III. Size, Function, and Life History. Cambridge, MA: Harvard Univ. Press, 1984.

Clutton-Brock J. Animals as Domesticates: A World View through History. East Lansing, 2012.

Collen B., Purvis A., Gittleman J.L. Biological correlates of description date in carnivores and primates. Global Ecol. Biogeogr. 2004; 13:459-467.

Cox R.M., Butler M.A., John-Alder H.B. The evolution of sexual size dimorphism in reptiles. Sex, Size and Gender Roles: Evolutionary Studies of Sexual Size Dimorphism. Eds. D.J. Fairbairn, W.U. Blanckenhorn, T. Székely, Oxford, 2007;38-49.
Dale J., Dunn P.O., Figuerola J., Lislevand T., Székely T., Wittingham L.A. Sexual selection explains Rensch's rule of allometry for sexual size dimorphism. Proc. R. Soc. B. 2007;274:2971-2979.

Daniels T.J. The social organization of free-ranging urban dogs. II. Estrous groups and the mating system. Appl. Anim. Ethol. 1983;10: 365-373.

Darwin C. On the Origin of Species by Means of Natural Selection. 1 st Edit. London, 1859.

Darwin C. The variation of animals and plants under domestication. London, 1868;I;II.

Darwin C. The Descent of Man and Selection in Relation to Sex. London, 1871;I;II.

Driscoll C.A., Menotti-Raymond M., Roca A.L., Karsten H., Johnson W.E., Geffen E., Harley E.H., Delibes M., Pontier D., Kitchener A.C., Yamaguchi N., O'Brien S.J., Macdonald D.W. The Near Eastern origin of cat domestication. Science. 2007;317:519-523.

Fairbairn D.J. Allometry for sexual size dimorphism: pattern and process in the coevolution of body size in males and females. Annu. Rev. Ecol. Syst. 1997;28:659-687.

Fairbairn D.J. Allometry for sexual size dimorphism: testing two hypotheses for Rensch's rule in the water strider Aquarius remigis. Am. Naturalist. 2005;66:S69-S84.

Fairbairn D.J. Introduction: the enigma of sexual size dimorphism. Evolutionary Studies of Sexual Size Dimorphism: Sex, Size and Gender Roles. Eds. D.J. Fairbairn, W.U. Blanckenhorn, T. Székely. Oxford, 2007;1-12.

Fairbairn D.J. Odd Couples: Extraordinary Differences between the Sexes in the Animal Kingdom. Oxford, 2013.

Fairbairn D.J., Blanckenhorn W.U., Székely T. (Eds.) Sex, Size and Gender Roles. Evolutionary Studies of Sexual Size Dimorphism. Oxford, 2007.

Frynta D., Baudyšová J., Hradcová P., Faltusová K., Kratochvíl L. Allometry of sexual size dimorphism in domestic dog. PLoS ONE. 2012;7(9):e46125. DOI 10.1371/journal.pone.0046125.

Galis F., Van Der Sluijs I., Van Dooren T.J.M., Metz J.A.J., Nussbaumer M. Do large dogs die young? J. Exp. Zool. (Mol. Dev. Evol.). 2007;308B:119-126. DOI 10.1002/jez.b. 21116.

Greer K.A., Canterberry S.C., Murphy K.E. Statistical analysis regarding the effects of height and weight on life span of the domestic dog. Res. Vet. Sci. 2007;82:208-214. DOI 10.1016/j.rvsc.2006.06.005.

Hart B.L., Hart L.A. Normal and problematic reproductive behaviour in the domestic cat. The Domestic Cat. The Biology of its Behaviour. 3rd Edit. Eds. D.C. Turner, P. Bateson. Cambridge, UK, 2014;27-36.

Hu Y., Hu S., Wang W., Wu X., Marshall F.B., Chen X., Wang C. Earliest evidence for commensal processes of cat domestication. Proc. Natl. Acad. Sci. USA. 2014;111:116-120. DOI/10.1073/pnas.1311439110.

Isaac J.L. Potential causes and life-history consequences of sexual size dimorphism in mammals. Mamm. Rev. 2005;35:101-115.

Lande R. Sexual dimorphism, sexual selection, and adaptation in polygenic characters. Evolution. 1980;34:292-305.

Lark K.G., Chase K., Sutter N.B. Genetic architecture of the dog: sexual size dimorphism and functional morphology. Trends Genet. 2006; 22:537-544. DOI 10.1016/j.tig.2006.08.009.

Larson G., Fuller D.Q. The evolution of animal domestication. Annu. Rev. Ecol. Evol. Syst. 2014;45:115-136. DOI 10.1146/annurevecolsys-110512-135813.

Larson G., Karlsson E.K., Perri A., Webster M.T., Ho S.Y.W, Peters J., Stahl P.W., Piper P.J., Lingaas F., Fredholm M., Comstock K.E., Modiano J.F., Schelling C., Agoulnik A.I., Leegwater P.A., Dobney K., Vignes J.-D., Vilà C., Andersson L., Lindblad-Toh K. Rethinking dog domestication by integrating genetics, archeology, and biogeography. Proc. Natl. Acad. Sci. USA. 2012;109:8878-8883. DOI 10.1073/ pnas. 1203005109 .

Legendre P. Package 'Imodel2' for R. http://cran.r-project.org/web/ packages/Imodel2.pdf. 2015.

Liao W.B., Zeng Y., Zhou C.Q., Jehle R. Sexual size dimorphism in anurans fails to obey Rensch's rule. Front. Zool. 2013;10:10. DOI 10.1186/1742-9994-10-10. 
Liberg O., Sandell M., Pontier D., Natoli E. Density, spatial organisation and reproductive tactics in the domestic cat and other felids. The Domestic Cat: The Biology of its Behaviour. 2nd Edit. Eds. D.C. Turner, P. Bateson. Cambridge, UK: Cambr. Univ. Press, 2000;119-147.

Lindenfors P., Gittleman J.L., Jones K.E. Sexual size dimorphism in mammals. Sex, Size and Gender Roles. Evolutionary Studies of Sexual Size Dimorphism. Eds. D.J. Fairbairn, W.U. Blanckenhorn, T. Székely. Oxford, 2007;16-26.

Lindenfors P., Tullberg B.S, Biuw M. Phylogenetic analyses of sexual selection and sexual size dimorphism in pinnipeds. Behav. Ecol. Sociobiol. 2002;52:188-193.

Lord K., Feinstein M., Smith B., Coppinger R. Variation in reproductive traits of members of the genus Canis with special attention to the domestic dog (Canis familiaris). Behav. Proc. 2013;92:131-142.

Martínez P.A., Bidau C.J. A re-assessment of Rensch's rule in tuco-tucos (Rodentia: Ctenomyidae: Ctenomys) using a phylogenetic approach. Mamm. Biol. 2016;81:66-72. DOI 10.1016/j.mambio.2014.11.008.

Martínez P.A., Amado T.F., Bidau C.J. A phylogenetic approach to the study of sexual size dimorphism in Felidae and an assessment of Rensch's rule. Ecosistemas. 2014;23:27-36.

Meiri S., Kadison A.E., Novosolov M., Pafilis P., Foufopoulos J., Itescu Y., Pincheira-Donoso D. The number of competitor species is unlinked to sexual dimorphism. J. Anim. Ecol. 2014;83:1302-1312.

O'Neill D.G., Church D.B., McGreevy P.D., Thomson P.C., Brodbelt D.C. Longevity and mortality of cats attending primary care veterinary practices in England. J. Feline Med. Surg. 2015;17:125133. DOI 1098612 X14536176.

Perri A. A wolf in dog's clothing: Initial dog domestication and Pleistocene wolf variation. J. Archaeol. Sci. 2016;68:1-4. DOI 10.1016/j. jas.2016.02.003

Peters R. The ecological implications of body size. Cambridge, UK, 1983.

Polák J., Frynta D. Sexual size dimorphism in domestic goats, sheep, and their wild relatives. Biol. J. Linn. Soc. 2009;98:872-883.

Polák J., Frynta D. Patterns of sexual size dimorphism in cattle breeds support Rensch's rule. Evol. Ecol. 2010;24:1255-1266. DOI 10.1007/ s10682-010-9354-9.

Pontier D., Fromont E., Courchamp F., Artois M., Yoccoz N.G. Retroviruses and sexual size dimorphism in domestic cats (Felis catus L.). Proc. R. Soc. B. 1998; 265:167-173.

Ranta E., Laurila A., Elmberg J. Reinventing the wheel: analysis of sexual dimorphism in body size. Oikos. 1994;70(3):313-321.

Reiss M.J. Sexual dimorphism in body size: are larger species more dimorphic? J. Theor. Biol. 1986;121:163-172.

Reiss M.J. The Allometry of Growth and Reproduction. Cambridge, UK, 1989.

Remeš V., Székely T. Domestic chickens defy Rensch's rule: sexual size dimorphism in chicken breeds. J. Evol. Biol. 2010;23:27542759. DOI 10.1111/j.1420-9101.2010.02126.x.

Rensch B. Die Abhangigkeit der Relativen Sexual differenz von der Korpergrosse. Bonner Zoologische Beiträge. 1950;1:58-69.

Rensch B. Evolution above the Species Level. N. Y., 1960.

Ruckstuhl K.E., Neuhaus P. (Eds.) Sexual Segregation in Vertebrates: Ecology of the Two Sexes. Cambridge, UK, 2005.

Sánchez-Villagra M.R., Geiger M., Schneider R.A. The taming of the neural crest: a developmental perspective on the origins of morphological covariation in domesticated mammals. R. Soc. Open Sci. 2016;3:160107. DOI 10.1098/rsos.160107.

Schmidt-Nielsen K. Scaling: Why is Animal Size so Important? Cambridge, UK, 1984.

Serpell J.A. Domestication and history of the cat. The Domestic Cat: The Biology of its Behavior. 3rd Edit. Eds. D.C. Turner, P. Bateson, Cambridge, UK, 2014;83-100.

Sibly R.M., Zuo W., Kodric-Brown A., Brown J.H. Rensch's rule in large herbivorous mammals derived from metabolic scaling. Am. Naturalist. 2012;179:169-177. DOI 10.5061/dryad.17vs2d34.

Simpson L.A., Ambrosio L.J., Baeza J.A. Sexual dimorphism and allometric growth in the enigmatic pygmy crab Petramithrax pygmaeus
(Bell, 1836) (Decapoda: Brachyura: Mithracidae), with a formal test of Rensch's rule in spider crabs (superfamily Majoidea). J. Crustacean Biol. 2016;36:792-803. DOI 10.1163/1937240x-00002486.

Skoglund P., Ersmark E., Palkopoulou E., Dalén L. Ancient wolf genome reveals an early divergence of domestic dog ancestors and admixture into high-latitude breeds. Curr. Biol. 2015;25:1515-1519. DOI 10.1016/j.cub.2015.04.019.

Smith R.J., Cheverud J.M. Scaling of sexual dimorphism in body mass: a phylogenetic analysis of Rensch's rule in Primates. Int. J. Primatol. 2002;23:1095-1135.

Stevens R.D., Platt R.N. Patterns of secondary sexual size dimorphism in new world Myotis and a test of Rensch's rule. J. Mammalogy. 2015;96:1128-1134. DOI 10.1093/jmammal/gyv120.

Sutter N.B., Mosher D.S., Gray M.M., Ostrander E.A. Morphometrics within dog breeds are highly reproducible and dispute Rensch's rule. Mamm. Genome. 2008;19:713-723. DOI 10.1007/s00335-0089153-6.

Székely T., Lislevand T., Figuerola J. Sexual size dimorphism in birds. Sex, Size and Gender Roles. Evolutionary Studies of Sexual Size Dimorphism. Eds. D.J. Fairbairn, W.U. Blanckenhorn, T. Székely. Oxford, 2007;27-37.

Thalmann O., Shapiro B., Cui P., Schuenemann V.J., Sawyer S.K., Greenfield D.L., Germonpré M.B., Sablin M.V., López-Giráldez F., Dominog-Roura X., Napierala H., Uerpmann H.P., Loponte D.M., Acosta A.A., Giemsch L., Schmitz R.W., Worthington B., Buikstra J.E., Druzhkova A., Graphodatsky A.S., Ovodov N.D., Wahlberg N., Freedman A.H., Schweizer R.M., Koepfli K.P., Leonard J.A., Meyer M., Krause J., Pääbo S., Green R.E., Wayne R.K. Complete mitochondrial genomes of ancient canids suggest a European origin of domestic dogs. Science. 2013;342:871-874. DOI 10.1016/j.jas.2016.02.003.

Torres-Romero E.J., Olalla-Tárraga M.A. Bergmann's rule in the oceans? Temperature strongly correlate with global interspecific patterns of body size in marine mammals. Global Ecol. Biogeogr. 2016; 25:1206-1215.

Trut L. Early canid domestication: the farm-fox experiment. Am. Scientist. 1999;87:160-169.

Trut L.N., Markel A.L., Borodin P.M., Argutinskaya S.V., Zakharov I.K., Shumny V.K. To the 90th anniversary of Academician Dmitry Konstantinovich Belyaev (1917-1985). Russ. J. Genetics. 2007;43(7):717-720.

Tubaro P.L., Bertelli S. Female-biased sexual size dimorphism in tinamous: a comparative test fails to support Rensch's rule. Biol. J. Linn. Soc. 2003;80:519-527.

Vigne J.D., Guilaine J., Debue K., Haye L., Gérard P. Early taming of the cat in Cyprus. Science. 2004;304:259-259.

Wallace A.R. Darwinism. London; New York, 1889.

Webb T.J., Freckleton R.P. Only half right: species with female-biased sexual size dimorphism consistently break Rensch's rule. PLoS ONE. 2007;9:e897. DOI 10.1371/journal.pone.0000897.

Weckerly F.W. Sexual-size dimorphism: influence of mass and mating systems in the most dimorphic mammals. J. Mammalogy. 1998;79: 33-52.

Werner Y.L., Korolker N., Guy S. Bergmann's and Rensch's rules and the spur-thighed tortoise (Testudo graeca). Biol. J. Linn. Soc. 2016; 117:796-811. DOI 10.1111/bij.12717.

Wilkins A.S., Wrangham R.W., Fitch W.T. The "domestication syndrome" in mammals: a unified explanation based on neural crest cell behavior and genetics. Genetics. 2014;197:795-808. DOI 10.1534/ genetics.114.165423.

Wu H., Jiang T., Huang X., Lin H., Wang H., Wang L., Niu H., Feng J. A test of Rensch's rule in Greater Horseshoe Bat (Rhinolophus ferrumequinum) with female-biased sexual size dimorphism. PLoS ONE. 2014;9(1):e86085. DOI 10.1371/journal.pone.0086085.

Zeder M.A. The domestication of animals. J. Anthropol. Res. 2012;68: 161-190.

Zeder M.A. Core questions in domestication research. Proc. Natl. Acad. Sci. USA. 2015;112:3191-3198. DOI 10.1073/pnas.1501711112. 